\title{
Monitoring of coastal and transitional waters under the E.U. Water Framework Directive
}

\author{
J. G. Ferreira • C. Vale • C. V. Soares • F. Salas • \\ P. E. Stacey • S. B. Bricker • M. C. Silva • \\ J. C. Marques
}

Received: 1 January 2006 / Accepted: 22 January 2007 / Published online: 7 March 2007

(C) Springer Science + Business Media B.V. 2007

\begin{abstract}
A set of guidelines are presented for the definition of monitoring plans in coastal and transitional (estuarine and lagoonal) systems subject to the European Union Water Framework Directive - WFD (2000/60/EC). General principles of best practice in monitoring are outlined, including (a) the definition of three types of broad management objectives: water quality, conservation, and human use, to which the general public may easily relate. These will define the core and research indicators (WFD quality elements) to be used for monitoring; (b) priorities and optimisation in a (financially and logistically) resourceconstrained environment; (c) quality assurance; and (d) assessment of monitoring success: this should focus on the outputs, i.e. the internal audit of the monitoring activity, and on the outcomes. The latter
\end{abstract}

J. G. Ferreira $(\bowtie)$

IMAR - Institute of Marine Research, IMAR-DCEA,

Fac. Ciências e Tecnologia, Qta Torre, 2829-516

Monte de Caparica, Portugal

e-mail: joao@hoomi.com

C. Vale

IPIMAR - Instituto de Investigação das Pescas e do Mar, Av. de Brasília, 1449-006

Lisboa, Portugal

C. V. Soares

Instituto Hidrográfico, Rua das Trinas 49,

1249-093 Lisboa, Portugal

F. Salas

Departamento de Ecología e Hidrología,

Facultad de Biología, Campus Universitario de Espinardo,

30100 Murcia, Spain component assesses programme effectiveness, i.e. environmental success based on a set of clearlydefined targets, and informs management action. The second part of this work discusses the approach and actions to be carried out for implementing WFD surveillance, operational and investigative monitoring. Appropriate spatial and temporal scales for surveillance monitoring of different indicators are suggested, and operational monitoring is classified into either screening or verification procedures, with an emphasis on the relationship between drivers, pressure, state and response. WFD investigative monitoring is interpreted as applied research, and thus guidelines cannot be prescriptive, except insofar as to provide examples of currently acceptable approaches. Specific case studies are presented for

\footnotetext{
P. E. Stacey

Connecticut Department of Environmental Protection, Bureau of Water Management, Hartford, CT, USA

S. B. Bricker

NOAA - National Ocean Service, National Centers for Coastal Ocean Science, 1305 East West Highway, Silver Spring, MD 20910, USA

M. C. Silva

LNEC - Laboratório de Engenharia Civil,

Av. do Brasil 101, 1700-066

Lisboa, Portugal

J. C. Marques

IMAR - Institute of Marine Research,

Faculdade de Ciências e Tecnologia,

Universidade de Coimbra,

3004-517 Coimbra, Portugal
} 
both operational (coastal eutrophication control) and investigative monitoring (harmful algal blooms), in order to illustrate the practical application of these monitoring guidelines. Further information is available at http://www.monae.org/.

Keywords Coastal waters · Estuary · Transitional waters $\cdot$ Surveillance monitoring $\cdot$ Operational monitoring · Investigative monitoring · E.U. Water Framework Directive $\cdot 2000 / 60 /$ EC $\cdot$ U.S. Clean Water Act $\cdot$ Management $\cdot$ MONAE

\section{Introduction}

The approval by the European Union of Directive 2000/60/EC (European Community 2000), commonly known as the Water Framework Directive (WFD), established a comprehensive set of objectives for water quality in European waters. This directive establishes a framework for community action in water policy and management concerns, and applies to all waters, including groundwater, inland surface water, and coastal and transitional waters. The various objectives defined in the WFD may be summarised into an overall goal: To achieve a good water status for all European Union waters by the year 2015.

The WFD stipulates that E.U. Member States must establish monitoring plans in order to assess the Ecological Status of their water bodies. This is done through the assessment of a range of Biological Quality Elements (BQE) and Supporting Quality
Elements (SQE), that together lead to a classification into one of five Ecological Status classes, ranging from High Status to Bad Status. The WFD innovates in a number of ways, amongst which is the requirement of a definition of type-specific reference conditions (Vincent et al. 2003), in recognition that different water types (e.g. different types of estuaries or lagoons) may be characterised by distinct definitions of quality, with respect to environmental metrics such as phytoplankton biodiversity (e.g. Ferreira et al. 2005), benthic species composition (e.g. Borja et al. 2000, 2004a; Salas et al. 2004) and SQE (Bald et al. 2005). The complexity of the WFD required the production of a set of guidance documents (European Commission 2006) and the scientific interpretation of many of its requirements has resulted in publications addressing issues such as water management (Mostert 2003), definition of water bodies (Ferreira et al. 2006), or risk assessment for quality status targets (Borja et al. 2006).

Monitoring programmes will determine the compliance of E.U. Member States with the reference conditions defined for each water type. Three types of monitoring programmes are defined in the WFD, each addressing different questions; these programmes consequently vary in scope in both (1) time and space, and (2) in the range of quality elements which need to be monitored (Table 1).

The goals and requirements of the U.S. Clean Water Act (CWA) are similar to those of the E.U. WFD, requiring states to regularly monitor and report on the condition of coastal water bodies within their jurisdiction (e.g. Gibson et al. 2000). The U.S.

Table 1 Types of monitoring defined in the WFD

\begin{tabular}{cl}
\hline $\begin{array}{c}\text { Monitoring type } \\
\begin{array}{c}\text { Surveillance } \\
\text { monitoring }\end{array}\end{array}$ & $\begin{array}{c}\text { Supplement and validate the assessment of the likelihood that transitional or coastal waters are failing to meet } \\
\text { the environmental quality objectives } \\
\text { Efficient and effective design of future monitoring programmes } \\
\text { Assess long-term changes in natural conditions in order to distinguish between non-natural and natural } \\
\text { alterations in the ecosystem } \\
\text { Assess long-term changes resulting from widespread anthropogenic activity }\end{array}$ \\
$\begin{array}{c}\text { Establish the status of those bodies identified as being at risk of failing to meet their environmental objectives } \\
\text { monitoring } \\
\text { Investigative } \\
\text { monitoring }\end{array}$ & $\begin{array}{l}\text { Whess any changes in the status of such bodies resulting from the programmes of measures } \\
\text { Where surveillance monitoring indicates that the objectives set under Article } 4 \text { for a body of water are not likely } \\
\text { to be achieved and operational monitoring has not already been established, in order to ascertain the causes of } \\
\text { a water body or water bodies failing to achieve the environmental objectives } \\
\text { To ascertain the magnitude and impacts of accidental pollution. }\end{array}$
\end{tabular}


Environmental Protection Agency (USEPA) defines the monitoring elements, which are detailed in EPAapproved state monitoring strategies. The monitoring programs are implemented through a federal-state partnership (USEPA 2003a). Monitoring programs are designed to assess attainment of state water quality standards and criteria, and are delegated to state water management authorities. States report to EPA on water quality status every two years as required by section 305(b) of the CWA (USEPA 2003a). The focus is on water bodies that do not meet specific chemical, physical or biological standards and criteria and are considered impaired. Identification of impairments, similar to designation of poor or bad status under the WFD, initiates management actions (response), including development of a management plan, to bring the water body into compliance. For chemical impairments, the water body is placed on a list identifying it as impaired under Section 303(d) of the CWA, which mandates listing of chemicallyimpaired water bodies, (USEPA 2003a). Section 303 (d) requires a detailed investigation of the condition, including monitoring and development of a Total Maximum Daily Load (TMDL) that establishes thresholds for chemical pollutant loading to a water body and a plan to attain that load (USEPA 2003b). In many ways, the U.S. CWA framework parallels the E.U. WFD requirements with the bi-annual monitoring and reporting equivalent to the surveillance monitoring of the WFD and the more intensive monitoring and TMDL development equivalent to the WFD operational and investigative monitoring. Although not as specifically constrained by Section 303(d) requirements, similar activities are undertaken at the state level to address physical and biological impairments when a relationship to a specific chemical pollutant does not exist or is uncertain.

Monitoring of coastal systems has been executed for many years within E.U. Member States prior to the approval of the WFD (e.g. De Jong et al. 1999; De Jonge et al. 2006; MEMG 2004). Work on monitoring approaches for surface waters under the WFD is ongoing, for instance in the application of GIS (Chen et al. 2004); In freshwaters, Friberg et al. (2005) have published a comprehensive plan for quality monitoring in Danish streams. The Monitoring Plan For Portuguese Coastal Waters - Water Quality and Ecology (MONAE) project (Ferreira et al. 2005) was commissioned by the government of Portugal to prepare a blueprint for WFD-compliant monitoring of coastal and transitional systems. This paper presents some of the findings from MONAE, and addresses the following objectives:

1. Definition and discussion of aspects which are of general application to any monitoring plan for surface waters;

2. Review and interpretation of the three different types of monitoring required by the WFD for coastal and transitional waters, bearing in mind optimisation issues due to logistic and financial constraints;

3. Proposal and justification of appropriate temporal and spatial coverage for different BQE/SQE and illustration of this through the application of case studies.

\section{Monitoring guidelines}

The following topics are covered as a general framework for any monitoring activity:

1. Definition of appropriate objectives

2. Setting priorities and optimisation

3. Implementation of quality control

4. Assessment of monitoring success

Definition of appropriate objectives

Although the general objective of monitoring specified in the WFD is to verify compliance with water quality objectives, or to establish the reasons for noncompliance so that appropriate measures may be put in place where applicable, a monitoring plan should examine these questions in broader terms, from the standpoint of ecosystem health. Monitoring activities that address a broad set of aims use indicators as proxies for these. In the WFD, these indicators must include the appropriate BQE and SQE, and may include others.

The indicators shown in Fig. 1 may have different levels of aggregation, ranging from, for example, combined indices of eutrophication or benthic quality status to the concentration of a particular parameter such as dissolved oxygen, and may be defined collectively as Environmental Quality Proxies (EQP). In the WFD these correspond to different combinations of BQE and SQE. Relevant objectives should be 
Fig. 1 Conceptual relationship between aims, indices, indicators and activities. ASSETS: ASSessment of Estuarine Trophic Status (Bricker et al. 2003); AMBI: Marine Biotic Index (Borja et al. 2000); TICOR: Typology and Reference Conditions for Portuguese Coastal Systems (Bettencourt et al. 2003)

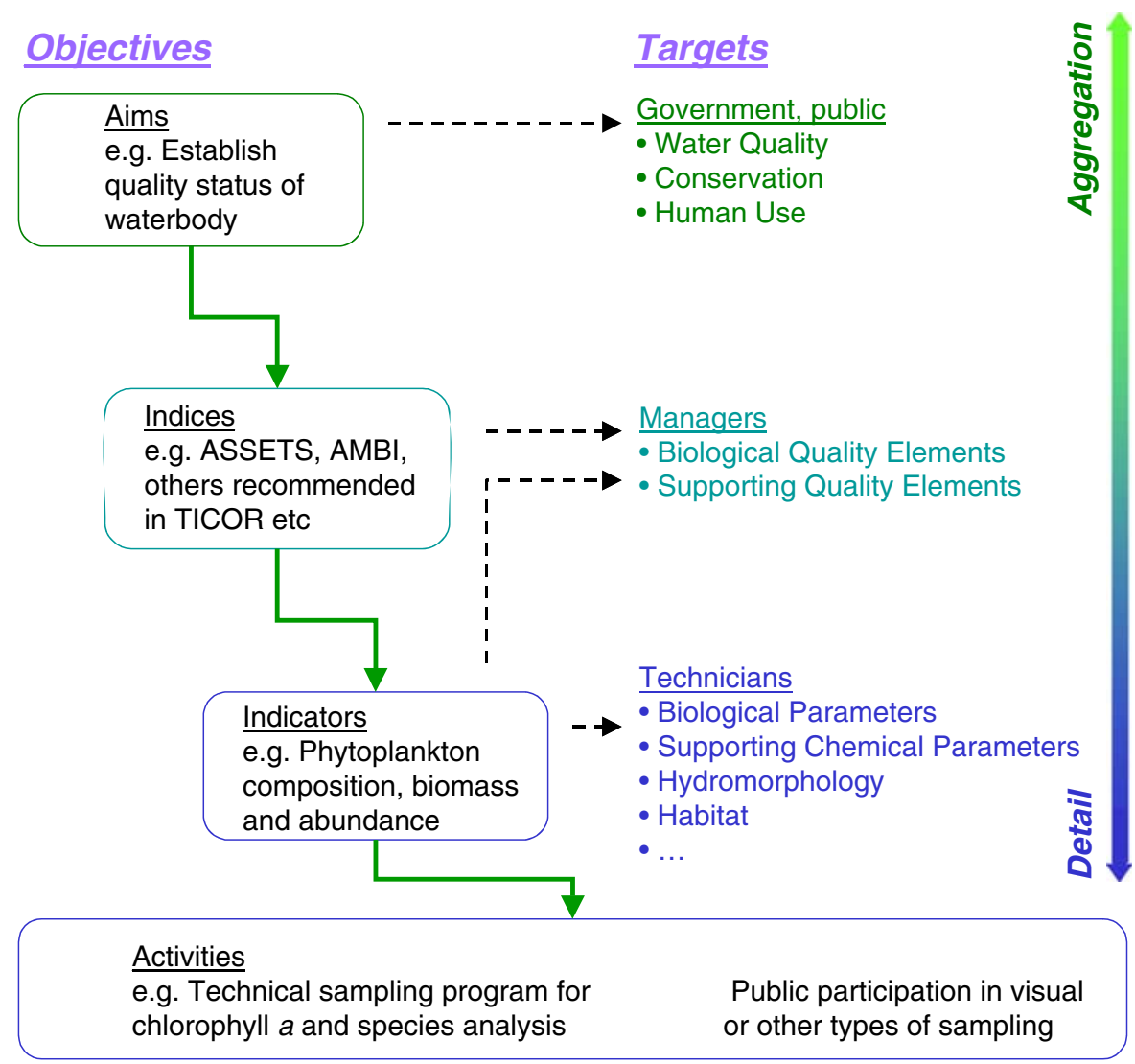

defined for management of Transitional and Coastal Waters (TCW), forming a set of goals which may need to be harmonised in time, space, and within the allowable EQP thresholds.

Three broad groups of management objectives may be defined:

1. Water quality objectives - e.g. (a) Restore and maintain a productive ecosystem with no adverse effects due to pollution; (b) Minimize health risks associated with contact water uses; (c) Estimate adverse impacts of eutrophication, including hypoxia resulting from human activities;

2. Conservation objectives - e.g. (a) Maintain on a landscape level the natural environment of the watershed; (b) Protect existing habitat categories within the watershed to preserve and improve regional biodiversity;

3. Human use objectives - e.g. (a) Support waterrelated recreation while preserving the economic viability of commercial endeavours; (b) Encourage sustainable lifestyles within the watershed, whereby human uses are balanced with ecosystem protection; (c) Empower citizens in the protection and stewardship of the coastal system (estuary, lagoon etc) and its watershed;

General objectives such as these have broad appeal, are easy to explain to a wide audience, and should be considered as bridges between ecosystem management at a technical and scientific level, political decisionmakers and the public at large. There is therefore a requirement that monitoring plans address these broad objectives, using EQP as assessment tools.

Core and research biological and supporting quality elements

A number of monitoring plans for coastal systems in the E.U. and U.S. have identified several types of indicators that can be used, which may be applied in a complementary manner to address the issues under consideration. These are typically divided into core and research indicators, and are evaluated in distinct types of monitoring plans. This fits in well with the concepts outlined in the WFD and developed in 
Table 2 Indicator list (abridged) for the Barnegat Bay monitoring plan

\begin{tabular}{ll}
\hline Primary indicators (high-profile indicators) & Secondary indicators (internal-use indicators) \\
\hline $\begin{array}{l}\text { Submerged aquatic vegetation distribution, abundance, } \\
\text { and health }\end{array}$ & Temperature and salinity \\
Land use/land cover change & $\begin{array}{l}\text { Dissolved oxygen and nutrients } \\
\text { Tignature species }\end{array}$ \\
Watershed integrity & $\begin{array}{l}\text { Phytoplankton abundance and composition \& chlorophyll } \\
\text { Shellfish beds }\end{array}$ \\
Bathing beaches & $\begin{array}{l}\text { Macrophyte abundance } \\
\text { Water-supply wells/drinking water }\end{array}$ \\
HAB & Shellfish and finfish abundance \\
Freshwater inputs & Benthic community structure \\
\end{tabular}

various guidance documents, i.e. that for surveillance monitoring the full spectrum of $\mathrm{BQE} / \mathrm{SQE}^{1}$ needs to be covered, for operational monitoring the indicators need to be far more targeted, and in the case of investigative monitoring the focus is on the detailed understanding of a specific issue.

An example of the types of indicators used in the Barnegat Bay (New Jersey, U.S.) monitoring plan is shown in Table 2 (Barnegat Bay National Estuary Program 2002). The distinction between primary (high-profile) and secondary (internal-use) is similar to the higher and lower levels of aggregation illustrated in Fig. 1. The use of indicators to define pressure, state and response characteristics and trends has grown in popularity. Indicators, particularly biological indicators that are more charismatic than chemical concentration data, for example, can provide more of an ecosystem perspective of conditions in estuarine and coastal waters that scientists, managers, politicians and the public find relevant and useful.

The Barnegat Bay example identifies a mix of indicators that relate to this wide constituency of scientists (e.g., chemical pollution and biological effects), managers (e.g., pollutant sources and land cover changes), and politicians and the public (e.g., fish and shellfish abundance and value, beach closures, and toxic contaminants in seafood). The full picture of a coastal system incorporates all these indicators to define cause and effect relationships that lead to necessary management outcomes.

\footnotetext{
${ }^{1}$ As required for the type-specific definition of reference conditions. Some elements may be excluded, e.g. due to high natural variability.
}

Furthermore, TCW monitoring programmes often need only slight modifications to ensure that a broad suite of useful indicators is built from the underlying parameter and media monitoring, that meets WFD objectives for comprehensive monitoring to assess ecosystem health status.

Priorities and optimisation

Monitoring plans must be established for a comprehensive coverage of transitional and coastal water bodies. The monitoring activities to be carried out constitute a serious additional workload on the technical and scientific communities in E.U. Member States, and due to logistic and/or financial constraints it may be necessary to prioritise different monitoring activities according to the management issues at hand. Additionally, models and prior monitoring efforts may provide enough insight into an ecosystem to improve efficiency by reducing sampling in time and space, using a more minimalist approach but still achieving monitoring objectives.

Figure 2 shows a decision-tree that may be used to define guidelines for prioritising monitoring activities. This approach takes into consideration:

(a) The definitions contained in the WFD for selection criteria of monitoring types - these definitions are sometimes ambiguous;

(b) The pressure (anthropogenic or non-anthropogenic) on the system;

(c) The susceptibility of the system, dependent on factors such as freshwater flushing time and tidal mixing; 
(d) The state of the system, assessed by means of Environmental Quality Proxies, i.e. BQE and SQE.

The monitoring actions, whilst important to defining pressure and state conditions, are the Response component of this framework, and correspond to different types of monitoring. In Fig. 2 these are discriminated by monitoring type, and colour-coded according to priority. Surveillance monitoring is not subject to ranking according to this scheme, since it is a requirement of WFD river basin plans.

Implementation of quality control

Data quality is an important consideration for any monitoring programme to ensure objectives are met and conclusions are not misled by inaccurate data. The USEPA provides detailed guidance for Quality Assurance Project Plans (QAPP) that cover all aspects of programme structure, quality assurance and control, and data analysis and reporting (USEPA 2000, 2001a). USEPA promotes a system that brings a final project design through policy, organisational, programmatic and, finally, project implementation components. The guidance documents include an evaluation of quality control in environmental modelling, a critical component of monitoring and assessment (USEPA 2002).

QAPPs need to consider all aspects of the monitoring activity, emphasizing standard and recognizable elements from planning through implementation and final assessment. As such, USEPA approval requires compliance with the following checklist:
Fig. 2 Decision-tree for selection of different types of monitoring programmes

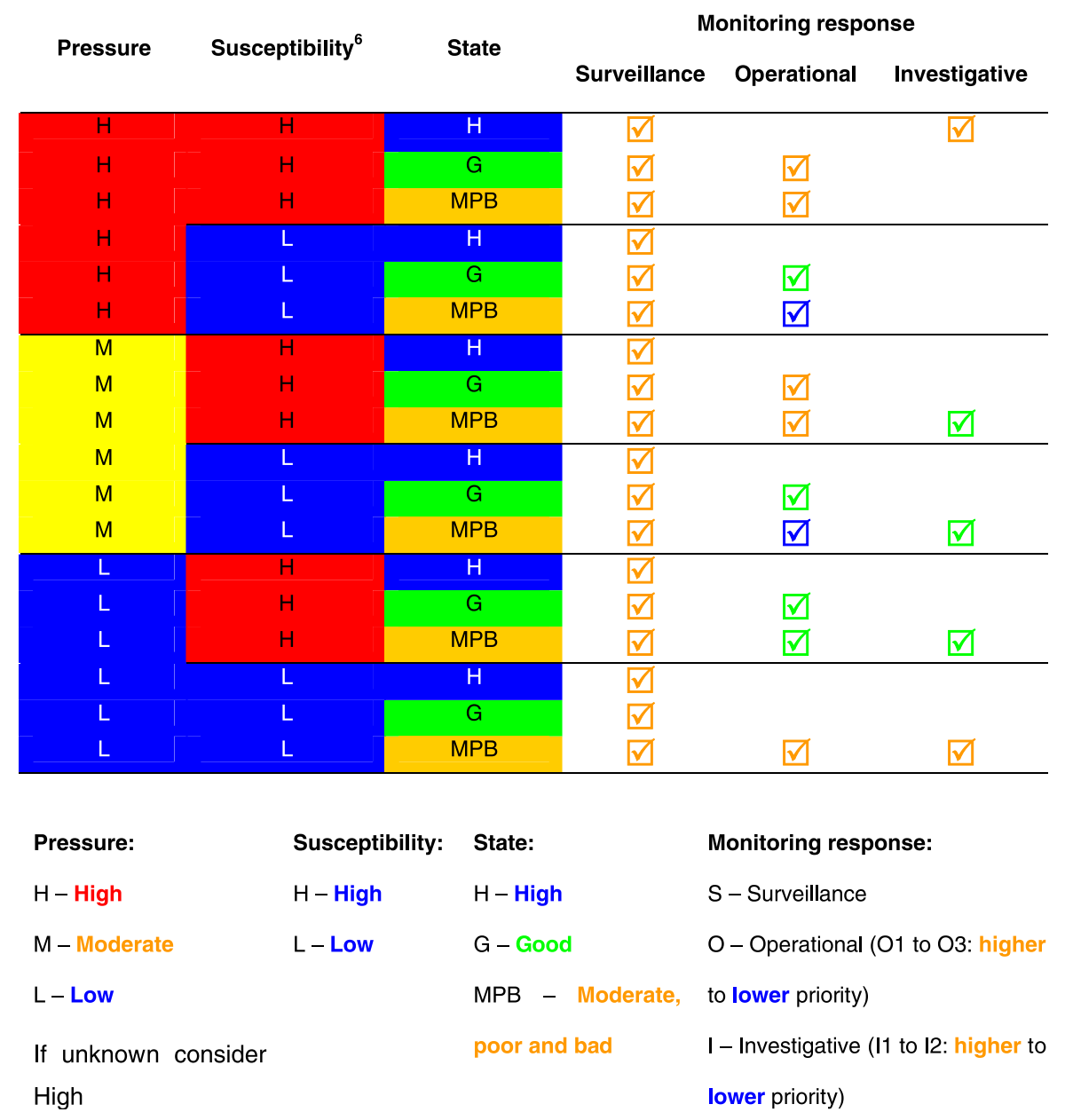

${ }^{6}$ Sensu e.g. Bricker et al. (2003)

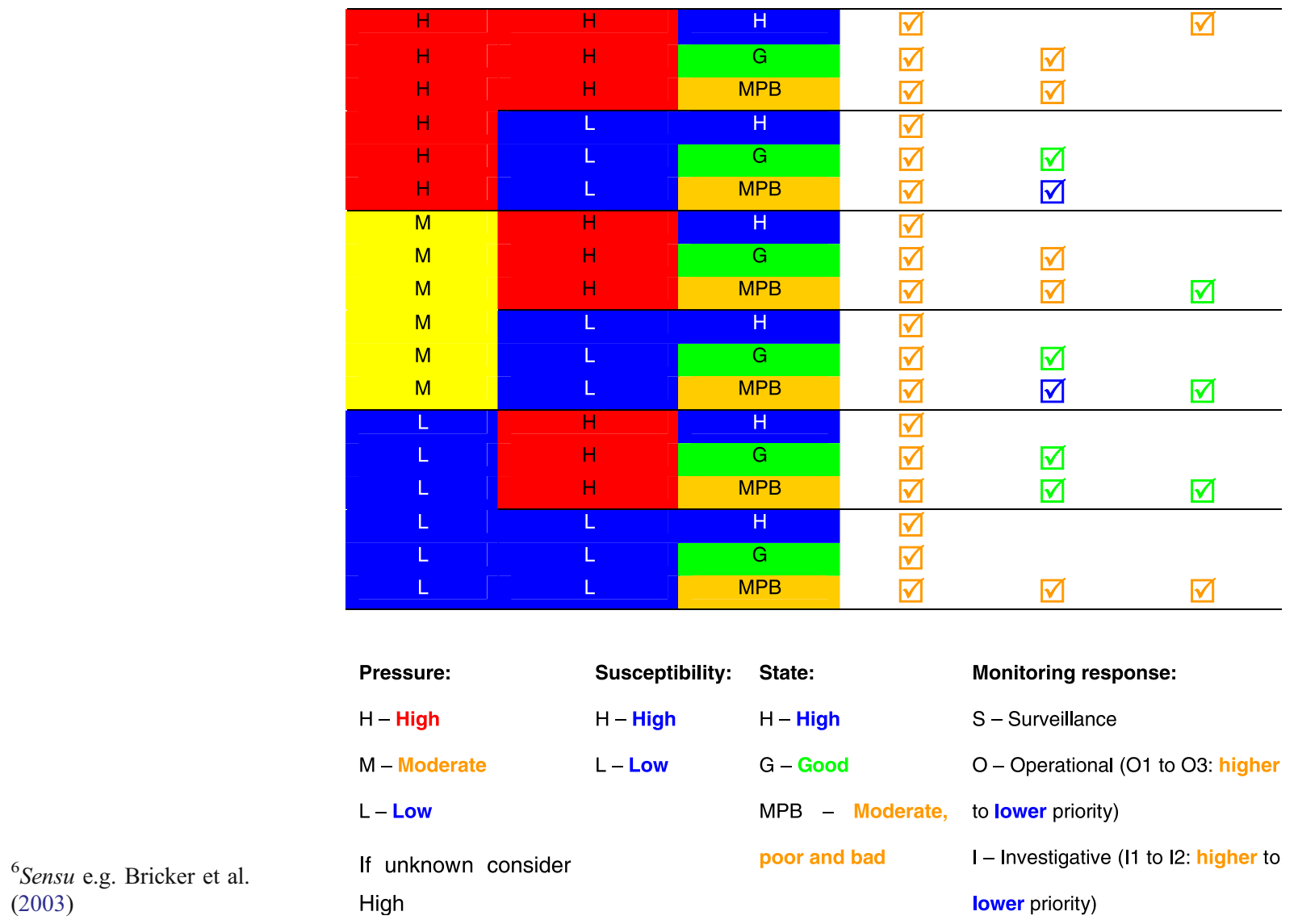


$\square$ The project technical and quality objectives are identified and agreed upon;

- The intended measurements, data generation, or data acquisition methods are appropriate for achieving project objectives;

$\square$ Assessment procedures are sufficient for confirming that data of the type and quality needed and expected are obtained;

Any limitations on the use of the data can be identified and documented.

Within this framework, QAPPs need to define and justify an appropriate project management structure, sound data generation and acquisition methodologies, a reasonable and statistically validated assessment and oversight procedure for quality assurance and control, and a process for ensuring data are valid and usable for the stated purposes and objectives of the programme. Of particular relevance is sound experimental design. The traditional components of a programme answer questions about the type and numbers of samples, the design of the network, locations, frequencies of collection, media sampled, and the parameters included. Standard procedures need to be specified - sample methods, handling and custody, and analytical methods.

Adequate quality control and assurance measures specific to the programme design that quantify precision, accuracy, bias, detection limits, procedural error, etc. must be included, together with plans to respond to any problems that arise. Typically, analytical programmes rely on duplicates, splits, blanks, spikes, and reference samples, among others, during both field and laboratory operations. Review is followed from field and laboratory procedures into data analysis and verification.

Appropriately validated banking of raw data is a fundamental component of the quality assurance process. Data collected in a monitoring programme must be stored in such a way as to allow a variety of treatments to be carried out. This includes, but is not limited to, statistical analyses, use in GIS and model calibration and validation. Finally, quality assurance for environmental models is an essential component of the complete monitoring process cycle. This becomes particularly significant as simulation results become progressively more integrated in regulatory activities. Key points highlighted by the EPA guidance and other sources include:

(a) Suitability for purpose

(b) Internal consistency

(c) Adequate calibration, validation and sensitivity testing

(d) Appropriate documentation

(e) Ease of use, including data input and output handling

Assessment of monitoring success

The success of each monitoring plan must be assessed in a clear way, providing a mechanism for evaluating the cost-benefit of the monitoring activity and for making necessary adaptations or corrections for future improvement.

Each monitoring plan must set out a number of objectives, which may be grouped into two different types:

1. Outputs: These are verifiable targets, which may be related to the terms of reference (i.e. Are the goals and objectives of the plan being met?), and is effectively an internal audit - verification that would include compliance with the various terms of reference for time, space, parameters, methodology, etc. This answers programmatic questions such as: (a) Is the sampling covering the estuaries/ coastal systems specified in the plan? (b) Is the strategy defined for a particular system (e.g. sampling according to a salinity gradient, particular vertical profiles or seasonality being followed? (c) Are the parameters being measured as required by the WFD? (d) Are methodology issues (intercalibration of methods, etc.) being handled as recommended?

2. Outcomes: This component assesses programme effectiveness, i.e. environmental success and informs management action. A distinct set of targets, based around specific ecological quality achievements, must answer questions such as: (a) Are shellfish/finfish areas increasing/decreasing? (b) Are salt marsh areas increasing/decreasing? (c) How is the frequency/spatial scope of elevated chlorophyll a evolving? (d) What are the observable trends for harmful algal bloom (HAB) 
events? (e) Are elevated nutrients correlated with elevated chlorophyll a? These questions should be centered around the BQE/SQE, and the indices into which these are aggregated.

As an example, for assessment of chlorophyll $a(\mathrm{BQE})$ and dissolved oxygen (SQE), which are respectively primary and secondary symptoms of eutrophication, monitoring success might be evaluated (1) at the outputs level by examination of compliance with monthly sampling within water bodies covering three estuarine salinity zones, considering appropriate depth profiling, analytical methods, etc.; and (2) at the outcomes level by determining whether the data collected provided sufficient information to answer questions on whether the impacted areas and deviation from state at reference conditions were increasing, and whether a correlation with nutrient loading could be established.

Figure 3 illustrates an (abridged) form taken from the Tillamook Bay (Oregon, U.S.) monitoring plan (Tillamook Bay National Estuary Program 1999). This plan provides a good example of a programme that addresses many of the design and quality assurance concerns identified above. The survey for eelgrass (Zostera sp.) in Tillamook Bay is developed on the basis of the metadata presented in this form, which include a clear definition of the metrics used to evaluate monitoring success.

The form states the general objective (outcome, as defined above) of the survey, allowing hypotheses (here adapted and posed as null) such as "The distribution of eelgrass is unchanged over a historical time period" or "The abundance of eelgrass is not being affected by nutrient enrichment" to be tested by managers. It additionally includes a management objective, "No net decline" - whilst this is not strictly a monitoring consideration, it is very useful to include the general management objective in such a list.

There are a number of logistic and administrative fields, and finally a sufficiently complete set of output indicators to allow a clear definition of the monitoring activity and subsequent internal audit.

\section{Surveillance monitoring}

Definition and objectives

The WFD states: "For each period to which a river basin management applies a surveillance monitoring shall be established. The objective of the surveillance monitoring is to provide information for:

(1) supplementing and validating the assessment of the likelihood that transitional or coastal waters will fail to meet the environmental quality objectives;

(2) the efficient and effective design of future monitoring programmes;

(3) the assessment of long-term changes in natural conditions in order to distinguish between nonnatural and natural alterations in the ecosystem;

(4) the assessment of long-term changes resulting from widespread anthropogenic activity.

The results of surveillance monitoring shall be reviewed and used in combination with the impact assessment to determine or adjust requirements for current and other monitoring programmes in the river basin management plans.

On the basis of these results, the risk of failing to meet WFD environmental objectives shall be evaluated in the surveyed water bodies and an operational monitoring programme established. Before implementing operational programmes and to ascertain the causes of a water body failing to achieve the environmental objectives, investigative monitoring shall be considered, which may provide insight into reasons for any unknown excess."

Design of a surveillance monitoring programme

The foremost concerns in the design of a surveillance monitoring programme are that (1) transitional and coastal water sampling stations within each river basin district are sufficient in number; and (2) observations are frequent enough to provide an assessment of the overall water status.

Surveillance monitoring shall be carried out for each monitoring site for a period of one year during the six-year period covered by a river basin management plan, unless the previous surveillance monitoring exercise showed that the body concerned has reached good status and there is no evidence of changes in impacts. In these cases, surveillance monitoring shall be carried out once every three river basin management plans, i.e. every 18 years. Monitoring shall include the quality elements listed in Table 3, and indicated in WFD Annex V. 


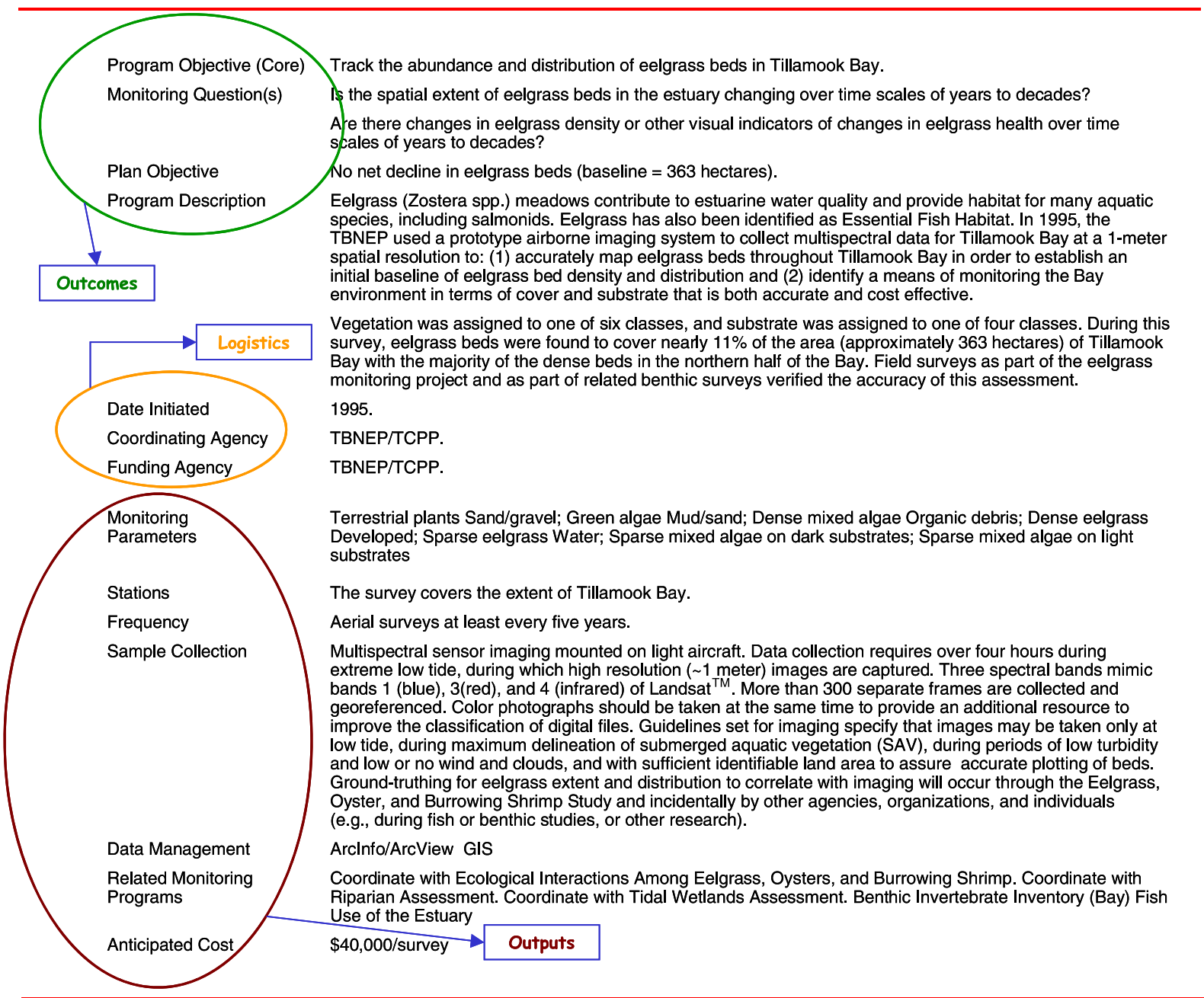

Fig. 3 Submerged Aquatic Vegetation survey, Tillamook Bay National Estuary Program (2005), abridged (Tillamook Bay National Estuary Program 1999)

\section{Spatial and temporal domain}

The frequency of observations used over the surveillance monitoring period shall be sufficient to obtain a representative picture of the water body status. The number of observations at each station will depend upon the variability in parameters resulting from both natural and anthropogenic conditions. The understanding of the time scales of processes relevant to water quality status, obtained from previous monitoring programmes or literature reviews, informs an appropriate choice of monitoring frequency. It is recommended that the times at which monitoring is undertaken shall be selected in order to ensure that the results reflect changes in the water body due to anthropogenic pressure rather than other influences.
The minimum monitoring frequencies indicated in Annex V of the WFD may not be adequate or realistic for TCW. There will generally be a lower level of confidence in most transitional systems when compared to freshwater because of the much higher natural variability and heterogeneity, therefore more samples may also be needed. Additionally, areas of special conservation interest, e.g. Natura2000 sites (Wätzold and Schwerdtner 2005; Weiers et al. 2004), may require a fuller sampling programme to verify compliance with complementary legislation such as the 92/43/EEC (Habitats) Directive. Where possible, a horizontal approach to monitoring should be taken, allowing resource optimisation in meeting the requirements of multiple directives. 
Table 3 Proposed surveillance monitoring frequencies of quality elements in coastal and transitional waters

Water bodies

(a) Open coastal water bodies

Quality elements

No influence of freshwater Submarine Influence of freshwater

canyon

Influence of urban

Biological

Phytoplankton

Seasonal

Every six

Seasonal

outfalls

Other aquatic flora

Annual if applicable months

Not

Macro invertebrates

Annual

Not

applicable

Fish

Not applicable

Not
applicable

Annual if applicable

Every six months

Not applicable

Seasonal

Hydromorphology

Depth variation

6 years

6 years

Structure of the bed

6 years

zone

Tides

Continuous

Currents and flows

6 years

Wave exposure

Continuous for one year every six years

18 years
18 years
Not
applicable
Not

Not

18 years

Not

applicable

6 years

6 years

6 years

Every six months if

applicable

Every six months

Physico-chemical

Transparency/Turbidity

Seasonal

Seasonal

Continuous

Not applicable

Thermal conditions

Seasonal

Seasonal

Seasonal

Salinity

Seasonal

Seasonal

6 years

Continuous for one year every six years

6 years

6 years

6 years

-

Nutrient status

Special Pollutants ${ }^{2}$

Seasonal

Seasonal

Seasonal

Seasonal

Seasonal

Seasonal

Continuous

Other pollutants

Annual $^{(2)}$

Seasonal

6 years

Continuous for one year every six years

Priority substances

Annual $^{(2)}$

Annual $^{(2)}$

Annual $^{(2)}$

Annual $^{(2)}$

Annual $^{(2)}$

Seasonal

Seasonal

Seasonal

Seasonal

Seasonal

Annual $^{(2)}$

Annual $^{(2)}$

(b) Restricted coastal and transitional water bodies

Quality element

Biological

Phytoplankton (biomass

and abundance)

Phytoplankton species

composition

Other aquatic flora

Macro invertebrates

Fish $^{3,4}$

Hydromorphology

Physico-chemical

Thermal conditions

Dissolved oxygen

Salinity

Nutrients

Special Pollutants ${ }^{5}$

Other pollutants

Priority substances

Frequency

Monthly

Every six months

Seasonal

Every six months

Seasonal

Variable

Monthly

Monthly

Monthly

Monthly

Every six months

Seasonal

\footnotetext{
${ }^{2}$ Sampling should be carried out in tissues of fish and shellfish and in sediments

${ }^{3}$ In the WFD, applicable only to transitional waters

${ }^{4}$ Observations shall where possible be synoptic with monitoring programmes related to the sustainable exploitation of commercial fish species

${ }^{5}$ Sampling should be conducted in suspended particulate matter, sediments and tissues of fish and shellfish
} 


\section{Open coastal waters}

Although the WFD applies only to a seaward limit of one nautical mile from the baseline of territorial waters, this may comprise a rather large area and volume of coastal water, in particular for nations which use straight lines across promontories or capes as the baseline (e.g. France, Ireland, Germany, Portugal, U.S.A.). These more extensive coastal waters are not directly influenced by river inputs or sewage discharges, and most of the changes in physico-chemical and biological parameters are due to natural conditions. Monitoring frequencies shall be chosen to achieve an acceptable level of long-term surveillance.

Table 3 contains a set of of proposals developed for Portuguese TCW in the MONAE programme, taking into account the Monitoring Guidance prepared by the European Commission (2003). The rationale is in general terms to optimise the information obtained, whilst working within resource limitations. The frequencies suggested are taken to be minimal requirements for adequately resolving the main processes of interest, and for the successful application of water quality and ecological models.

Table 3a summarises a set of proposed sampling frequencies of quality elements. The frequencies differ, but sampling should always take place synoptically, e.g. samples collected at three-month periods for a particular element should coincide with monthly samples for relevant elements. The vertical sampling resolution should be determined according to the water temperature and salinity gradients, but always include at least a surface and a deep water sample (above and below the pycnocline for a stratified water column).

\section{Transitional and inshore coastal waters}

These include estuaries and coastal waters in the proximity of estuaries or lagoons, where water status is influenced by the magnitude of discharges as well as by their tidal and seasonal fluctuations. Monitoring frequencies of pelagic $\mathrm{BQE}$ and $\mathrm{SQE}$ shall take into consideration the tidal and seasonal variability. At each station in estuaries and coastal lagoons with permanent connection to the sea it is recommended that all these parameters be measured at least at high and low tide, supplemented by sampling at mid-ebb and mid-flood where appropriate.

We propose that spatial resolution will be determined on the basis of the water bodies defined for each system (Ferreira et al. 2006) with at least one station per water body. This addresses a "paradox" within the WFD, whereby "Member States must be sure that all Water Bodies have Good Ecological Status but only a subset may be sampled." Alternatively, monitoring may be used for testing the hypothesis: If Water Body $\mathrm{X}$ is at Good Ecological Status with certain pressures, Water Body $\mathrm{Y}$ is also at Good Ecological Status if it has (a) Similar susceptibility; (b) Equivalent pressure indicators; (c) Loads in similar relative positions (e.g. with reference to the salinity distribution).

The vertical resolution for BQE and SQE measured in the water column should be determined (a) by the depth of the station, and (b) by the degree of stratification. The following general guidelines are suggested for vertical sampling in transitional and inshore coastal waters, building on the general orientation from the European Commission (2003):

At stations with depth less than $2 \mathrm{~m}$ (with respect to tidal datum), only mid-water samples will be collected, unless there is clear salinity and/or temperature stratification;

$\square$ At stations with depth of 2-4 m (with respect to tidal datum), surface and bottom samples will be collected. If clear salinity and/or temperature stratification exists, an additional mid-water sample will be taken;

At stations with depth of 4-10 m (with respect to tidal datum), surface, mid-water and bottom samples will be collected;

At stations with depth greater than $10 \mathrm{~m}$ (with respect to tidal datum), appropriate vertical profiling will be used, based on salinity and/or temperature stratification.

Table $3 \mathrm{~b}$ summarizes a set of proposed sampling frequencies for quality elements. The frequencies shown for quality elements differ, but sampling should always take place synoptically, e.g. samples collected at three-month periods for a particular element should coincide with monthly samples for relevant elements. 


\section{Operational monitoring}

\section{Definition and objectives}

Operational monitoring as defined by the WFD focuses on two specific objectives: (a) Establish the status of those bodies identified as being at risk of failing to meet their environmental objectives; (b) Assess any changes in the status of such bodies resulting from the programmes of measures. In both cases, the objectives are to verify the status of a water body or set of water bodies, with respect to one or more WFD quality elements.

Except in extreme cases of pressure across a range of substances (nutrients, metals, organic pollutants, etc.), this means that whereas surveillance monitoring is broader in scope, and as a rule less targeted, operational monitoring will generally focus on a subset of quality elements, e.g. primary and secondary eutrophication symptoms in the case of nutrientrelated problems (Bricker et al. 2003).

Identification of water bodies at risk and verification of measures

The first objective (screening) of operational monitoring is concerned with further investigation into a water body which is at risk of non-compliance with environmental objectives, i.e. which appears from surveillance monitoring data to be at moderate, poor or bad status for one or more quality elements. Operational monitoring is interpreted to be applicable mainly for water bodies diagnosed as being at moderate status, where more detailed studies will help establish the status of the water body. Figure 2 presents guidelines for managers to decide on the inception of operational monitoring as regards the first objective. It is intended as a primer for detailed data analysis on a case by case basis, on which final decisions will be based.

The second objective (verification) is to verify post-facto if management measures are working, i.e. from a Pressure-State-Response perspective, if a reduction in pressure due to management response has resulted in the expected change in state. The prediction of the change in state that will result from changes in pressure may only be made using the same approaches used for definition of reference conditions:
1. Comparison to historical data;

2. Comparison to system(s) of identical type in pristine condition;

3. Application of ecological models;

4. Heuristic evaluation.

The evaluation of the changes in status is made through the comparison of predictions and measurements.

Design of an operational monitoring programme

The guidelines for the design of operational monitoring will be determined by the quality elements that are under scrutiny, and whether the monitoring is being implemented to address screening or verification. The two objectives are discussed separately below, despite the fact that there are some common points.

\section{Operational monitoring for screening}

The decision to implement operational monitoring for screening purposes should be based on (a) the results of surveillance monitoring; (b) the pressures on a water body; or (c) both of these. Situations such as (1) high pressure combined with good state or (2) low pressure combined with bad state (Fig. 2) clearly need further interpretation. One of the key aspects in the design of this type of operational monitoring is the accurate assessment of anthropogenic pressure, including source apportionment, necessary in order to determine the possible responses in various situations.

TCW exhibit changes in state that may appear to be decoupled from the pressure on the system. For instance, in the case of coastal eutrophication:

1. The symptoms are diverse, variable in time and space, may potentially be due to a range of causes, and vary greatly in severity;

2. Although there is an association between pressure and state, the relationship between them is strongly influenced by geomorphology and hydrodynamics: TCW subject to similar nutrient-related pressure often exhibit totally different eutrophication symptoms, and in some cases no symptoms at all. Factors such as water residence time, tidal range and turbidity play a major role in determining the nature and magnitude of symptom expression;

3. Biological interactions, particularly due to grazing, may provide a top-down control of eutrophication symptoms. These may occur in similar 
types of TCW, due to natural variability, but also due to human activities such as shellfish aquaculture. In the latter case, selective filtration by bivalves may additionally affect biodiversity by altering the phytoplankton species composition.

Conversely, Fig. 4 shows a situation where a chlorophyll-rich water mass is moving inshore (left to right panes), illustrating how a potential $\mathrm{HAB}$ event causes impairment of coastal waters (Miller et al. 2005). These events, caused for example by upwelling relaxation, are observed regularly off the Iberian Peninsula, Ireland, the U.S. NE and NW coasts, and many other coastal areas. No reduction in pressure will correct phenomena of this type, since they are natural occurrences. Coastal waters subject to this type of "natural pressure" are only amenable to remedial management measurements such as interdiction of shellfish collection.

The design of a monitoring programme of this kind, which aims to screen water bodies and systems, must therefore take into account (a) the measurement of state, where the design considerations are those indicated in the surveillance monitoring section as regards particular quality elements; (b) the determination of pressure to establish whether there is a match between pressure and state; (c) source apportionment if required, in order to inform appropriate management measures.

\section{Operational monitoring for verification}

The design of an operational monitoring programme for verification of compliance presupposes that there is a clear hypothesis that relates the anthropogenic pressure to the ecological status.

In all cases, the null hypothesis being tested for one or more quality elements is: "The change in anthropogenic pressure as a result of management response does not result in a change of state." The hypothesis is tested e.g. to verify whether decreased pressure improves state, or if increased pressure deteriorates state. In many cases, a reduction in pressure will result in an improvement of state, but in some cases, such as the HAB example in Fig. 4, it will not. The key design consideration is therefore the testing of this hypothesis, which must include a number of steps below, following the operational monitoring programme:

1. Verify that the change in pressure is actually occurring;
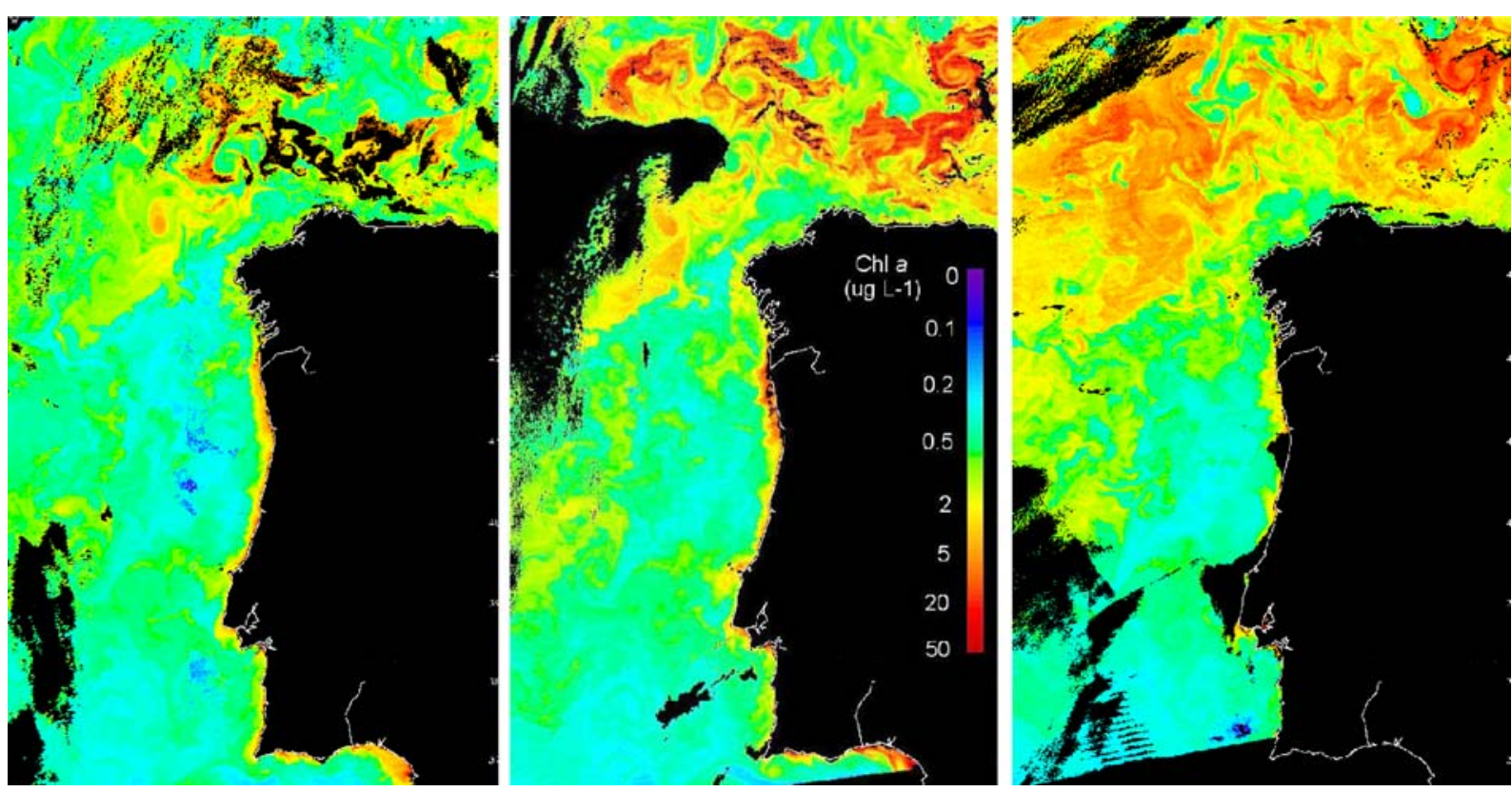

Fig. 4 Potential impairment of coastal waters by phytoplankton (represented as chlorophyll $a$ ) advected from offshore fronts (courtesy Plymouth Marine Laboratory) 
2. Determine the state for the relevant quality element(s) using surveillance monitoring guidelines;

3. Test the results against predictions of state changes due to management response;

4. Accept or reject the effectiveness of measures.

Case study: Eutrophication control

An analysis of the potential effects of reduction in nutrient loading for the Ria Formosa in southern Portugal is presented as a case study for implementation of operational monitoring for verification, by using an ecological model to simulate changes in pressure (due to measures) and testing the effectiveness on changes in system state.

The eutrophication status of the Ria Formosa was determined by means of the ASSETS screening model (Bricker et al. 2003). The resulting eutrophication grade of Moderate, which corresponds to a WFD classification of Moderate, was determined on the basis of data collected over a number of years for primary and secondary eutrophication symptoms. In parallel, an ecological model was developed for the Ria (Fig. 5), to simulate water exchange, nutrient dynamics, pelagic and benthic production, and clam aquaculture, a major use of the system, for nine different compartments (boxes). The outputs of this model were used to drive the screening model (Nobre et al. 2005). Four scenarios were run on the research model: pristine, standard (simulates present loading), half and double the current nutrient loading.

The Ria Formosa has a short water residence time, and eutrophication symptoms are not apparent in the water column. However, benthic symptoms are expressed as excessive macroalgal growth and strong dissolved oxygen fluctuations in the tide pools. The standard simulation results showed an ASSETS grade identical to the field data application. The application of the screening model to the other scenario outputs showed the responsiveness of ASSETS to changes in pressure, state and response, scoring a grade of High under pristine conditions, Good for half the standard scenario and Moderate for double the present loadings. The use of this hybrid approach allows managers to test the outcome of measures against a set of well-defined metrics for the evaluation of state.

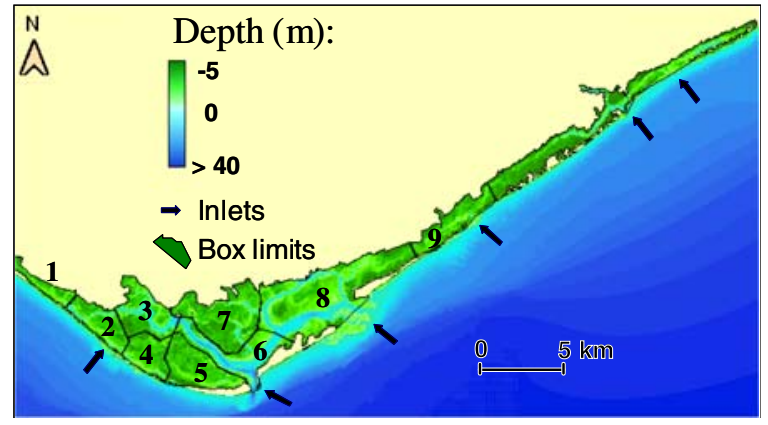

Fig. 5 Ria Formosa, showing ecological model boxes (see Nobre et al. 2005)

Figure 6 shows the results obtained for the research model "green" scenario, corresponding to a $50 \%$ reduction in nitrogen loading. From an operational monitoring standpoint, the results generated by the research model could be compared to measured data after the implementation, using a variety of techniques, such as trend analysis or statistical comparisons. More importantly, the ASSETS screening model, which is a potentially valuable tool for the implementation of the WFD in TCW (Borja et al. 2006; Ferreira et al. 2005; Nobre et al. 2005), could be applied to the data set collected in the verification programme, and the results compared with the screening model classification shown in Fig. 6. A detailed analysis of the application of these models is given in Nobre et al. (2005) and references therein.

\section{Investigative monitoring}

Cases where investigative monitoring is required

The Water Framework Directive specifies three cases where this type of monitoring is required:

1. Where the reason for any exceedences (of Environmental Objectives) is unknown;

2. Where surveillance monitoring indicates that the objectives set under Article 4 for a body of water are not likely to be achieved and operational monitoring has not already been established, in order to ascertain the causes of a water body or water bodies failing to achieve the environmental objectives;

3. To ascertain the magnitude and impacts of accidental pollution. 


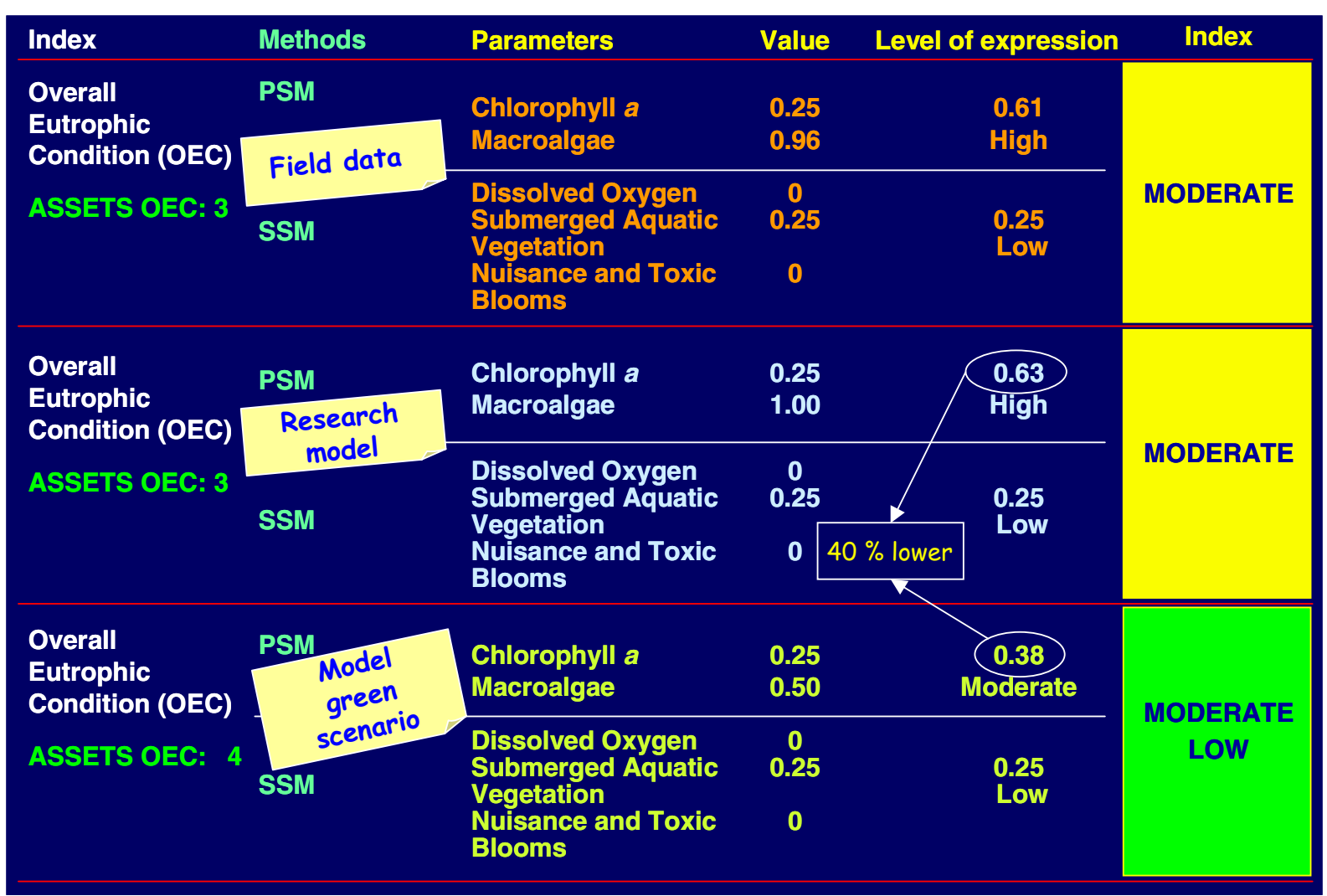

Fig. 6 Application of ASSETS to various research model scenarios. PSM - Primary Symptoms Method; ${ }^{\mathrm{d}}$ SSM - Secondary Symptoms Method. These are combined in a matrix which provides a combined score using the area-weighted average for primary eutrophication symptoms and the area-weighted maximum for secondary eutrophication symptoms, resulting in the classification shown in the right column

The results of the monitoring would then be used to establish a programme of measures to achieve the environmental objectives and specific measures necessary to remedy the effects of accidental pollution. Investigative monitoring will thus be designed for the specific case or problem being investigated. In some cases it will be more intensive in terms of monitoring frequencies and focused on particular water bodies or parts of water bodies, and on relevant quality elements. Ecotoxicological monitoring and assessment methods would in some cases be appropriate for investigative monitoring.

Investigative monitoring might also include alarm or early warning monitoring, for example, for protection against accidental pollution. This type of monitoring could be considered as part of the programmes of measures required by Article 11.3(a) of the WFD and could include continuous or semi- continuous measurements of a few chemical (such as dissolved oxygen) and/or biological (such as fish) determinants. Investigative monitoring may involve other determinants, sites and frequencies than surveillance or operational monitoring, as each programme will be designed to assess a specific stress or impact.

Approaches in investigative monitoring

Investigative monitoring relies by definition on a variety of approaches, which will generally be conjugated to provide answers to the research questions being asked (e.g. Allan et al. 2006; Dworak et al. 2005). Estuaries and coastal zones are often highly energetic systems, due to the effects of river discharges, waves and tides, so the representation of physical processes is usually required to help clarify the phenomena of interest. These physical tools 


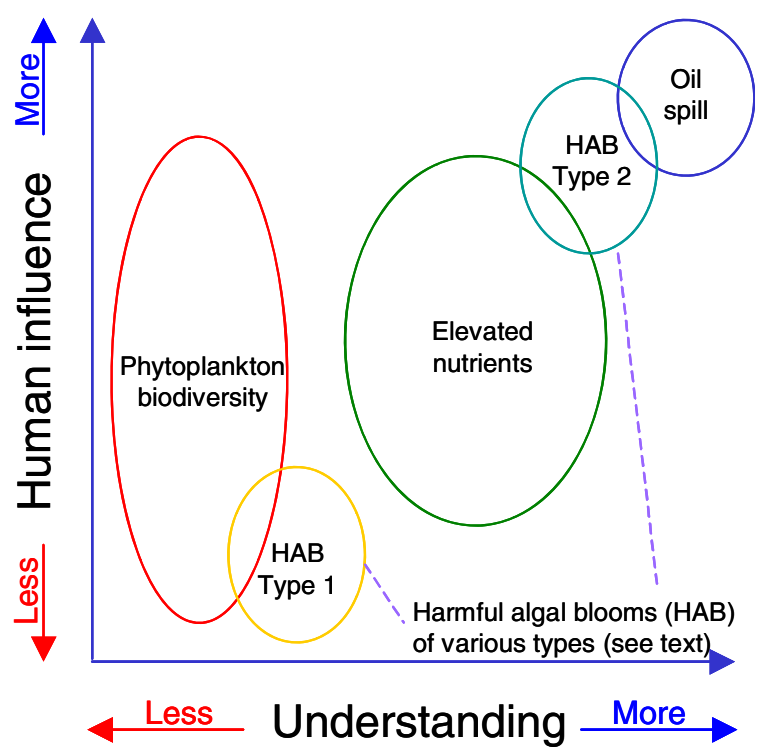

Fig. 7 Examples of environmental problems in marine systems, scaled by human influence and process understanding

should be used in conjunction with chemical and biological techniques, which are selected according to the objectives of the work.

Investigative monitoring of the marine environment is by nature interdisciplinary, with the problems addressed being diverse, and constrained by different levels of understanding. Issues range e.g. from the interpretation of the effects of an accidental oil spill, where most processes are well understood, to the understanding of changes in biodiversity, affecting e.g. phytoplankton or benthic species composition, which are rather poorly understood (Fig. 7). The level of uncertainty in our understanding of underlying processes responsible for a particular environmental effect, and the corresponding apportioning of human influence (which conditions the possibility and adequacy of the response), is thus a major factor in the planning, execution and potential success of an investigative monitoring programme. In some cases the same problem may have completely different causes, e.g. HAB may be clearly linked to anthropogenic influence (e.g. cyanophyte blooms in the Baltic Sea) and therefore amenable to management measures (e.g. Turner et al. 1998), or perhaps be advected to coastal areas from offshore fronts (e.g. Fraga et al. 1988; Joyce and Pitcher 2004), and therefore not manageable in terms of emission control.
Overview of methodologies

Due to the constraints described above, it is only appropriate here to provide some examples of methodologies that may be used to address research questions (i.e. perform investigative monitoring) on biological, supporting (chemical), and hydromorphological quality elements. Additionally, it should be recognised that (a) methodologies are constantly under development (e.g. molecular probes, chemotaxonomic methods, DNA barcodes, improved in situ instrumentation, remote sensing); and (b) future paradigm shifts will potentially make some of these methods obsolete, as has occurred in the past for example following the development of remote sensing applications or mathematical models. It is therefore recommended that investigative monitoring should always draw on the best available techniques, combining the state of the art in field determinations, laboratory experiments and simulation models in order to provide the answers to the investigative monitoring questions posed by managers and scientists.

Application of biomarkers for investigative monitoring

Biomarkers are discussed below as an example of a powerful tool for use in investigative monitoring, targeted at xenobiotics.

\section{Biomarkers as an investigative monitoring tool}

France and the U.K. have explored possibilities to include bioassays in the WFD; in most other countries bioassays and biomarkers are applied at a research level and/or in national monitoring programmes related to the OSPAR Commission for the Protection of the Marine Environment of the North-East Atlantic (1999). Moreover, in the U.S. bioassays are a federal requirement of state-delegated programmes for monitoring point source effluents as part of the discharge licensing process.

When warranted, field bioassays of water and sediment may be incorporated into state environmental monitoring programmes to ascertain causes of aquatic life use impairments and to track down toxic contaminant sources. Sediment bioassays are also an 
integral component of testing materials to be dredged if there is an expectation that the sediments are toxic based on bulk analyses. In this sense, Borja et al. (2004b) point out the importance of the inclusion of sediment analyses and the use of biomonitors in the determination of the quality standards of the WFD.

Although it is not specifically mentioned in the WFD, the WGBEC (2004) determined that there are clear opportunities for the use of bioassays in two ways:

1. To predict whether the chemical quality is sufficient to achieve high ecological status, using risk analysis;

2. To determine whether chemicals are the cause of not achieving good ecological status.

Bioanalysis may be regarded as a partial replacement of chemical analysis of priority and/or other relevant substances, and prioritising locations for further chemical analysis. It is defined as the application of a small set of inexpensive and rapid assays representing various taxonomic groups and/or modes of action applied to an extract of a water (or sediment) sample.

For bioassays, the WGBEC (2004) recommended whole sediment bioassays using the mud shrimp Corophium and the lugworm Arenicola marina, and bioassays of sediment pore waters, sea water elutriates, and sea water samples with bivalve embryos and the planktonic copepod Acartia. These two types of bioassays are non-contaminant specific and can provide a retrospective interpretation of community changes. Moreover, WGBEC (2004) recommended different techniques for biological monitoring programmes, some of which are pollutant specific (e.g. imposex for TBT, bulky DNA adduct formation and phytohemagglutinin bile metabolism methods for PAH and other synthetic organic compounds). Other methods such as lysosomal stability, lysosomal retention and the "scope for growth" method, are not specific and respond to a wide variety of contaminants. The first two methods provide a link between exposure and pathological endpoints, and the "scope for growth" method is a sensitive measure of sublethal effects such as energy available for growth in bivalve molluscs (e.g. Savina and Pouvreau 2004; Wang et al. 2005).
Sampling procedures and frequency

The sampling procedures and their frequency of application will depend on the method selected to investigate the cause and the magnitude of specific stress or impact. In general terms, near-zone monitoring (e.g., caging of bivalves for testing purposes) and wider area field surveys need to consider the biology of the target organism. In particular, periods of natural stress might need to be avoided, such as the spawning period when there may be large fluxes of contaminants out of the organism with the release of eggs. The OSPAR Joint Assessment and Monitoring Programme (OSPAR Commission for the Protection of the Marine Environment of the North-East Atlantic 2004) has produced guidelines for general biological effects monitoring with technical annexes describing the methodology, sampling procedures and frequency of different bioassays and biological methods. Several European projects such as BEQUALM (2002) have developed protocols and procedures for biological methods used in marine monitoring.

The role of target species

Bivalve molluscs have been one of the most frequently used indicators to determine the existence and quantity of a toxic substance. The advantages of using bivalves in environmental monitoring are: (1) wide distribution; (2) simplicity of sampling; (3) sedentary nature; (4) tolerance to a wide range of environmental conditions; and (5) high potential for bioconcentration of environmental toxicants due to high filtration activity.

Due to their sessile nature, wide geographical distribution and capability to detoxify when pollution ceases, mussels such as Mytilus, cockles such as Cerastoderma and clams such as Donax have long been considered ideal for the detection of toxic substances in the environment. This broadly corresponds to the "Mussel Watch" concept (Goldberg et al. 1978). Likewise, certain species of crustacea and polychaete worms are considered capable of accumulating toxic substances.

Many fish species have also been used for the study of toxic pollution of the marine environment, due to their bioaccumulative capability and the existing relationship between pathologies suffered by 
Table 4 Examples of methodologies for investigative monitoring of HABs

\begin{tabular}{ll}
\hline Methodology & Study objective \\
\hline Physical oceanography (field studies, moorings) & Vertical migration, water column stability \\
Remote sensing & Biomass and primary productivity determination, bloom tracking, model validation \\
Micropaleontology & Cyst distribution in sediments \\
Molecular probes & Toxicity assessment of facultative HAB species \\
Numerical models & Prediction of HAB population development and distribution \\
Cost-benefit analysis & Evaluation of socio-economic costs of recurring HAB events \\
\hline
\end{tabular}

benthic fish and the presence of polluting substances (e.g. USEPA 2001b; NOAA 2004). Commercial and recreational fish species consumed by humans are also indicators of potential human health risk when specified thresholds for contaminant accumulation are exceeded; the implications are readily understood by the general public.

Case study: Harmful algal blooms

HAB are caused by many different species of phytoplankton, and can have widely varying effects (Smayda 1997). They cause significant ecological and economic damage, for example through impacts on fisheries, aquaculture, human health and tourism. HABs may occur in open coastal waters and in semi-enclosed/enclosed systems, with a trend towards the occurrence of toxic algae in the former and high biomass blooms in the latter. The investigation of the causes and development of HAB events thus requires a range of methodologies (Table 4).

The Ecology and Oceanography of Harmful Algal Blooms ECOHAB (n.d.) programme (NOAA 2005a), initiated in the U.S. in 1995, included three broad research themes:
- Organisms - To determine physiological, biochemical and behavioural features influencing bloom dynamics;

$\square$ Environmental regulation - To determine and parameterise the factors controlling the onset, growth and maintenance of HABs;

$\square$ Food-web and community interactions - To determine the extent to which food webs and trophic structure affect and are affected by HABs.

A general aim of Ecology and Oceanography of Harmful Algal Blooms ECOHAB (n.d.) was to develop reliable models to predict bloom initiation, development, duration and toxicity. The MERHAB program is a complementary initiative aimed at monitoring and event response for HAB (NOAA 2005b).The EUROHAB initiative is a similar programme that has been carried out in the E.U. since 1999, clustering research projects such as BIOHAB and ECOHARM.

As an example of the application of currently available investigative monitoring techniques, field and simulation studies in the Gulf of Maine, U.S. (McGillicuddy $\mathrm{Jr}$ et al. 2005), revealed a number of physical and biological mechanisms which play a key

Table 5 Hypothesis-driven monitoring approach

\begin{tabular}{ll}
\hline Hypothesis & Examples \\
\hline $\begin{array}{l}\text { H0: Changes in environmental status and health are } \\
\text { unrelated to human pressures. }\end{array}$ & $\begin{array}{l}\text { Red tide events in Portuguese coastal waters are unrelated to human use; } \\
\text { Changes in estuarine turbidity are unrelated to increased organic } \\
\text { production; } \\
\text { Given the nature of the Portuguese Atlantic coast, the only state changes } \\
\text { in the coastal waters due to basin pressures are in xenobiotics in offshore } \\
\text { sediments. }\end{array}$ \\
$\begin{array}{l}\text { H0: Changes in (abiotic) Supporting Quality Elements are changes in dissolved nutrients do not have a discernible effect on } \\
\text { not reflected in Biological Quality Elements. }\end{array}$ & $\begin{array}{l}\text { Statrophication symptoms such as chlorophyll } a \text { concentration; } \\
\text { State changes of xenobiotics in offshore waters do not presently have a } \\
\text { discernible effect on marine biota. }\end{array}$
\end{tabular}


role in the generation and maintenance of blooms of the toxic dinoflagellate Alexandrium fundyense:

1. Cysts of this species were found to germinate in bottom sediments far from shore;

2. Field mapping surveys revealed a large cyst repository situated offshore of Casco and Penobscot Bays, at a depth of $150 \mathrm{~m}$, with densities greater than 20 times those in inshore waters;

3. The role of these deep-water cysts in coastal HABs was studied by means of a mathematical model, which allowed the identification of an entrainment mechanism based partly on the behaviour of the toxic organism and partly on the wind-driven transport of a plume of low salinity water trapped in the surface layer;

4. The HAB cells germinated from deep-water cysts swim actively towards the light, enter the thin surface layer and are advected to the coast due to favourable onshore winds.

This case study illustrates the need to understand the cause-effect relationships that underpin HABs, through a combination of research tools. The affected area would in all likelihood violate environmental objectives, but conventional measures centered on the reduction of land-based nutrient discharges would not be an appropriate management response.

\section{Conclusions}

The implementation of the WFD raises many challenges, which are widely shared by European Union Member States. These include (1) the complexity of the text and the range of possible solutions to scientific, technical and practical questions; (2) the extremely demanding timetable; (3) the incomplete technical and scientific basis with some fundamental issues in Annex II and V, which need further elaboration in order to make the transition from principles and general definitions to practical implementation successful; and (4) a strict limitation of human and financial resources. Most of these general issues are also applicable to states of the U.S., under the CWA.

A well-designed monitoring programme should endeavour to test one or more hypotheses, even if the baseline objective is verification of the compliance status of a set of water bodies to the requirements of the WFD. A statement of the hypotheses to be tested, and the methodologies to be used to perform the tests must be a part of any monitoring plan. In the case of surveillance and operational monitoring, the hypotheses may address broad questions, such as those listed in the left column of Table 5. General hypotheses such as these may be refined to address specific issues, depending on the systems under consideration. The right column gives examples of this type of specification.

Operational monitoring will need to follow a drivers-pressure-state-response approach, particularly as regards the verification of measures, which constitute the management response. This is considered appropriate by other authors (e.g. Borja et al. 2006; Elliott 2000) and is clearly an interface area between monitoring and ecological modelling. Investigative monitoring programmes are by definition aimed at hypothesis testing, in order to further understanding of key processes. These must therefore be built on the basis of meaningful research questions and take the form of scientific research projects.

The classification of monitoring by the WFD into these three types is somewhat arbitrary, and in particular it is questionable whether investigative monitoring really fits into the general definition of monitoring or could be better described as applied research. Nevertheless, the concepts and application of guidelines presented herein will help to structure and improve many monitoring schemes, avoiding a frequent situation where large volumes of data are collected in a deus ex machina process, and subsequently prove of little use to inform management decisions.

Partly this occurs because the various disciplines required for an ecosystem approach to coastal monitoring are not sufficiently integrated, even at the level of diagnosis of state, and certainly as regards interfacing with land use, hydrological processes and effluent discharge patterns in the relevant watersheds. The development of a more structured approach to the monitoring process will provide numerous direct benefits, and well-designed surveillance and operational monitoring may additionally be leveraged for subsequent complementary (and typically more specific and detailed) investigative programmes. 
Acknowledgements The authors are grateful to INAG for supporting this work. We also wish to express our thanks to the MONAE project team for helpful comments, to Plymouth Marine Laboratory for access to remote sensing data, and to two anonymous referees for their constructive comments on an earlier manuscript draft.

\section{References}

Allan, I. J., Vrana, B., Greenwood, R., Mills, G. A., Roig, B., \& Gonzalez, C. (2006). A "toolbox" for biological and chemical monitoring requirements for the European union's Water Framework Directive. Talanta, 69, 302322.

Bald, J., Borja, A., Muxika, I., Franco, J., \& Valencia, V. (2005). Assessing reference conditions and physico-chemical status according to the European Water Framework Directive: A case-study from the Basque Country (Northern Spain). Marine Pollution Bulletin, 50, 1508-1522.

Barnegat Bay National Estuary Program (2002). Final comprehensive conservation and management plan, completed under a cooperative agreement between U.S. Environmental Protection Agency Region 2 and the New Jersey Department of Environmental Protection, Barnegat Bay National Estuary Program, Ocean County College, Toms River, NJ. http://www.bbep.org/ccmp.htm.

Bettencourt, A., Bricker, S. B., Ferreira, J. G., Franco, A., Marques, J. C., Melo, J. J., et al. (2003). Typology and reference conditions for Portuguese transitional and coastal Waters. Development of guidelines for the application of the European Union Water Framework Directive. INAG/IMAR, 2003. http://www.ecowin.org/ticor.

Biological Effects Quality Assurance in Monitoring Programmes (BEQUALM) (2002). http://www.bequalm.org/.

Borja, A., Franco, J., \& Pérez, V. (2000). A marine biotic index to establish the ecological quality of soft-bottom benthos within European estuarine and coastal environments. Marine Pollution Bulletin, 40(12), 1100-1114.

Borja, A., Franco, J., Valencia, V., Bald, J., Muxika, I., Belzunce, M. J., et al. (2004a). Implementation of the European Water Framework Directive from the Basque Country (Northern Spain): A methodological approach. Marine Pollution Bulletin, 48, 209-218.

Borja, A., Galparsoro, I., Solaun, O., Muxika, I., Tello, E., Uriarte, A., et al. (2006). The European Water Framework Directive and the DPSIR, a methodological approach to assess the risk of failing to achieve good ecological status. Estuarine, Coastal and Shelf Science, 66, 84-96.

Borja, A., Valencia, V., Franco, J., Muxika, I., Bald, J., Belzunce, M. J., et al. (2004b). The Water Framework Directive: Water alone, or in association with sediment and biota, in dtermining quality standards? Marine Pollution Bulletin, 49, 8-11.

Bricker, S. B., Ferreira, J. G., \& Simas, T. (2003). An integrated methodology for assessment of estuarine trophic status. Ecological Modelling, 169(1), 39-60.

Chen, Q., Zhang, Y., Ekroos, A., \& Hallikainen, M. (2004). The role of remote sensing technology in the E.U. Water
Framework Directive (WFD). Environmental Science \& Policy, 7(4), 267-276.

De Jong, F., Bakker, J. F., van Berkel, C. J. M., Dankers, N. M. J. A., Dahl, K., Gätje, C., et al. (1999). Wadden sea quality status report. Wadden sea ecosystem No. 9', Common Wadden Sea Secretariat, Trilateral Monitoring and assessment Group, Quality Status Report Group. Wilhelmshaven, Germany, p. 259.

De Jonge, V. N., Elliott, M., \& Brauer, V. S. (2006). Marine monitoring: Its shortcomings and mismatch with the E.U. Water Framework Directive's objectives. Marine Pollution Bulletin, 53, 5-19.

Ecology and Oceanography of Harmful Algal Blooms (ECOHAB), undated. http://www.cop.noaa.gov/stressors/ extremeevents/hab/current/fact-ecohab.html.

Ecology and Oceanography of Harmful Algal Blooms (ECOHAB), undated. http://www.whoi.edu/ecohab/.

Dworak, T., Gonzalez, C., Laaser, C., \& Interwies, E. (2005). The need for new monitoring tools to implement the WFD. Environmental Science \& Policy, 8, 301-306.

Elliott, M. (2000). The role of the DPSIR approach and conceptual models in marine environmental management: An example for offshore wind power. Marine Pollution Bulletin, 44, iii-vii.

European Community (2000). Directive of the European Parliament and of the Council 2000/60/EC, establishing a framework for community action in the field of water policy, p. 62.

European Commission (2003). Monitoring under the Water Framework Directive. European Commission, CIS Guidance document $\mathrm{N}^{\circ}$ 7, p. $153 \mathrm{http}$ ://forum.europa.eu.int/ Public/irc/env/wfd/library?l=/framework_directive/guidance_ documents $\& v m=$ detailed $\&$ sb $=$ Title.

European Commission (2006). Common implementation strategy guidance documents, http://forum.europa.eu.int/ Public/irc/env/wfd/library?=/framework_directive/guidance documents $\& v m=$ detailed $\& s b=$ Title.

EUROHAB. http://www.nioz.nl/nioz_nl/e55082b2e503bc f730ee326e48126f2a.php.

Ferreira, J. G., Bettencourt, A., Bricker, S. B., Marques, J. C., Melo, J. J., Newton, A., et al. (2005). Monitoring plan for water quality and ecology of Portuguese transitional and coastal waters. Development of guidelines for the application of the European Union Water Framework Directive, http://www.monae.org.

Ferreira, J. G., Nobre, A. M., Simas, T. C., Silva, M. C., Newton, A., Bricker, S. B., et al. (2006). A methodology for defining homogeneous water bodies in estuaries - Application to the transitional systems of the E.U. Water Framework Directive. Estuarine, Coastal and Shelf Science, In Press.

Ferreira, J. G., Wolff, W. J., Simas, T. C., \& Bricker S. B. (2005). Does biodiversity of estuarine phytoplankton depend on hydrology? Ecological Modelling, 187(4), 513-523.

Fraga, S., Anderson, D. M., Bravo, I., Reguera, B., Steidinger, K. A., \& Yentsch, C. M. (1988). Influence of upwelling relaxation on dinoflagellates and shellfish toxicity in Ria de Vigo, Spain. Estuarine, Coastal and Shelf Science, 27(4), 349-361.

Friberg, N., Baattrup-Pedersen, A., Lauge Pedersen, M., \& Skriver, J. (2005). The new Danish stream monitoring programme (Novana) - preparing monitoring activities for 
the Water Framework Directive era. Environmental Monitoring and Assessment, 111(1-3), 27-42.

Gibson, G. R., Bowman, M. L., Gerritsen, J., \& Snyder, B. D. (2000). Estuarine and coastal marine waters: Bioassessment and biocriteria technical guidance. EPA822-B-00024. U.S. Environmental Protection Agency, Office of Water, Washington, DC.

Goldberg, E. D., Bowen, V. T., Farrington, J. W., Harvey, G., Martin, J. H., Parker, P. L., et al. (1978). The mussel watch. Environmental Conservation, 5, 101-125.

Joyce, L. B., \& Pitcher, G. C. (2004). Encystment of Zygabikodinium lenticulatum (Dinophyceae) during a summer bloom of dinoflagellates in the southern Benguela upwelling system. Estuarine, Coastal and Shelf Science, 59(1), 1-11.

McGillicuddy Jr., D. J., Anderson, D. M., Solow A. R., \& Townsend, D. W. (2005). Interannual variability of Alexandrium fundyense abundance and shellfish toxicity in the Gulf of Maine. Deep Sea Research Part II: Topical Studies in Oceanography, 52(19-21), 2843-2855.

MEMG, Marine Environment Monitoring Group (2004). UK National Marine Monitoring Programme - Second Report (1999-2001). Centre for Environment, Fisheries \& Aquaculture Science, CEFAS, p. 136.

Miller, P. I., Shutler, J. D., Moore, G. F., \& Groom, S. B. (2005). SeaWiFS discrimination of harmful algal bloom evolution. International Journal of Remote Sensing, 27 (11), 2287-2301.

Mostert, E. (2003). The European Water Framework Directive and water management research. Physics and Chemistry of the Earth, 28(12-13), 523-527.

National Oceanic and Atmospheric Administration (NOAA) (2004). Monitoring data - benthic surveillance, NOAA NCCOS CCMA. http://www8.nos.noaa.gov/cit/nsandt/ download/bs_monitoring.aspx.

National Oceanic and Atmospheric Administration (NOAA) (2005a). Ecology and Oceanography of Harmful Algal Blooms (ECOHAB), NOAA NCCOS CSCOR, http:// www.cop.noaa.gov/stressors/extremeevents/hab/current/ fact-ecohab.html.

National Oceanic and Atmospheric Administration (NOAA) (2005b). Monitoring and Event Response for Harmful Algal Blooms (MERHAB), NOAA NCCOS CSCOR, http://www.cop.noaa.gov/stressors/extremeevents/hab/current/fact-merhab.html.

Nobre, A. M., Ferreira, J. G., Newton, A., Simas, T., Icely, J. D., \& Neves, R. (2005). Management of coastal eutrophication: Integration of field data, ecosystem-scale simulations and screening models. Journal of Marine Systems, 56(3/4), 375-390.

OSPAR Commission for the Protection of the Marine Environment of the North-East Atlantic (1999). Guidelines. http:// www.ospar.org/asp/ospar/dra.asp?id=3.

OSPAR Commission for the Protection of the Marine Environment of the North-East Atlantic (2004). OSPAR Strategy for the Joint Assessment and Monitoring Programme (JAMP). http://www.ospar.org/eng/html/strategies/strategy06.htm.

Salas, F., Neto, J. M., Borja, A., \& Marques, J. C. (2004). Evaluation of the applicability of a marine biotic index to characterize the status of estuarine ecosystems: The case of Mondego estuary (Portugal). Ecological Indicators, 4, 215-225.

Savina, M., \& Pouvreau, S. (2004). A comparative ecophysiological study of two infaunal filter-feeding bivalves: Paphia rhomboïdes and Glycymeris glycymeris. Aquaculture, 239(1-4), 289-306.

Smayda, T. J. (1997). Harmful algal blooms: Their ecophysiology and general relevance to phytoplankton blooms in the sea. Limnology and Oceanography, 42, 1137-1153.

Tillamook Bay National Estuary Program (1999). Restoring the balance - comprehensive conservation and management plan for Tillamook Bay, Oregon. Tillamook Bay National Estuary Program, Garibaldi, Oregon, completed under Cooperative Agreement CE-980127-01 with the U.S. Environmental Protection Agency. http://www.tbnep.org/ reports/ccmp.html.

Tillamook Bay National Estuary Project (2005). http://www.co. tillamook.or.us/gov/Estuary/homepage.htm.

Turner, R. K., Adger, W. N., \& Lorenzoni, I. (1998). Towards integrated modelling and analysis in coastal zones: Principles and practices. LOICZ Reports and studies $\mathrm{N}^{\circ} 11$, iv+122 pp. LOICZ IPO, Texel, Netherlands.

United States Environmental Protection Agency (USEPA) (2000). Quality manual for environmental programs. Office of Environmental Information, Quality Staff, 5360A1, http:/www.epa.gov/quality/qs-docs/5360.pdf.

United States Environmental Protection Agency (USEPA) (2001a). Requirements for quality assurance project plans. Office of Environmental Information, EPA QA/R-5, Rept. EPA/240/B-01/003, Office of Environmental Information, Washington, DC. p. 40. http:/www.epa.gov/quality/qsdocs/r5-final.pdf.

United States Environmental Protection Agency (USEPA) (2001b). National Coastal Condition Report (2001) download site. http://www.epa.gov/owow/oceans/nccr/downloads. html.

United States Environmental Protection Agency (USEPA) (2002). Guidance for quality assurance project plans for modeling. Office of Environmental Information, EPA QA/ G-5M, http://www.epa.gov/quality/qs-docs/g5m-final.pdf.

United States Environmental Protection Agency (USEPA) (2003a). Elements of a state water monitoring and assessment program. Assessment and Watershed Protection Division. Office of Wetlands, Oceans and Watershed. U. S. Environmental Protection Agency. EPA 841-B-03-003. p. 24. http:/www.epa.gov/owow/monitoring/elements/.

United States Environmental Protection Agency (USEPA) (2003b). Guidance for 2004 Assessment, Listing and Reporting Requirements Pursuant to Sections 303(d) and 305(b) of the Clean Water Act. United States Environmental Protection Agency, Office of Water, Office of Wetlands, Oceans, and Watersheds.

Vincent, C., Heinrich, H., Edwards, A., Nygaard, K., \& Haythornthwaite, J. (2003). Guidance on typology, classification and reference conditions for transitional and coastal waters, European Commission, report of CIS WG2.4 (COAST), p. 119 http://forum.europa.eu.int/Public/

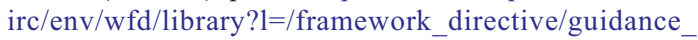
documents $\& v m=$ detailed $\& s b=$ Title. 
Wang, S., Hong, H., \& Wang, X. (2005). Bioenergetic responses in green lipped mussels (Perna viridis) as indicators of pollution stress in Xiamen coastal waters, China. Marine Pollution Bulletin, 51(8-12), 738-743.

Wätzold, F., \& Schwerdtner, K. (2005). Why be wasteful when preserving a valuable resource? A review article on the cost-effectiveness of European biodiversity conservation policy. Biological Conservation, 123(3), 327-338.
Weiers, S., Bock, M., Wissen, M., \& Rossner, G. (2004). Mapping and indicator approaches for the assessment of habitats at different scales using remote sensing and GIS methods. Landscape and Urban Planning, 67(1-4), 43-65.

WGBEC (2004). Report of the Working Group on Biological effects of contaminants, Ostend, 22-26 March 2004, ICES CM 2004/E:04. 